\title{
Comparative analysis of physio chemical characteristics of dyeing industry effluent between Sanganer and Bagru printing clusters, Jaipur (Rajasthan)
}

\author{
Sunil k. Sharma ${ }^{1}$,Neetu Sharma ${ }^{2}$,Yogesh khandelwal ${ }^{3}$ \\ ${ }^{1}$ Department of Chemistry and Environment Engineering. Jagannath University, India \\ ${ }^{2}$ Department of Chemistry and Environment Engineering. University of Rajasthan, India \\ ${ }^{3}$ Department of Mathematics, Jaipur National University, India
}

\begin{abstract}
In this investigation we compare the physicochemical properties such as BOD, COD, $p H, T D S$, and $E C$ of bagru and sanganer textile cluster dyeing effluent with the discharge limit prescribed by rajasthan state pollution control board (RPCB ) and we found that some of physio chemical data are exceed from prescribe limit by RPCB, in sanganer cluster condition are very critical rather then bagru, in sangner cluster mainly used synthetic dyes with dye mordants and in bagru mainly natural and vegetables dyes are used with mordants, in dyeing process $20 \%$ of dyes are unfixed on fabric and this unfixed dye mix with the effluent which are responsible for higher value of physiochemical properties in these area. data show that effluent loaded with high organic load and other toxic chemicals.
\end{abstract}

Keywords: Textile industry, Textile effluent, Discharge limit, physio chemical properties

\section{Introduction}

Dyeing and printing industry represent an important economic sector for Sanganer and Bagru are two important printing clusters of Jaipur. Bagru cluster famous for hand block printing there are 250 printing units located in the south-west of Jaipur region at a distance of about $40 \mathrm{~km}$ from Jaipur city on National Highway (NH-8) towards Ajmer. This town is located between north latitude $26^{\circ} 48^{\prime} 07^{\prime \prime}$ to $26^{\circ} 50^{\prime} 18^{\prime \prime}$ and east longitude $275^{\circ} 32^{\prime} 07^{\prime \prime}$ to $75^{\circ} 34^{\prime} 06^{\prime \prime}$. whereas Sanganer is famous for dyeing there are 600 dyeing units located $20 \mathrm{~km}$ away from the main city in south of Jaipur and lying $26^{\circ} 49^{\prime}-26^{0} 51^{\prime} \mathrm{N}$ and $75^{\circ} 46^{\prime}-75^{\circ} 51^{\prime}$ E.. In Bagru vegetable and natural dyes are used for coloring fabric whereas a number azo dyes are used in Sanganer dyeing industries. printing and dyeing industry requires a huge volume $25 \%$ of total water for printing and dyeing processing. Generally the untreated waste water effluent is released in water sources. These effluents, with their high biological oxygen demand(BOD) and chemical oxygen demand(COD) and suspended solids are very toxic in nature.

\subsection{Collection of sample}

\section{Material And Method}

For the present analysis, dyeing effluent samples were collected from local drainage in study areas and designated as $\mathrm{SN}_{1}, \mathrm{SN}_{2}, \mathrm{SN}_{3}$ for Sanganer cluster samples and $\mathrm{BG}_{1}, \mathrm{BG}_{2}, \mathrm{BG}_{3}$ for Bagru cluster samples in closed containers and stored at cold place. Collected samples were analyzed of five parameters such $\mathrm{pH}$, electrical conductivity, BOD, COD and TDS by standard methods prescribed by APHA $(1998,2012)$.

\subsection{Methods and Apparatus}

Deluxe $\mathrm{pH}$ meter $-101,1302283$, manufactured by EI was used for $\mathrm{pH}$ measurement, to determine the electro-conductivity of waste water sample, a measured volume of sample in the beaker was prepared and Deluxe conductivity meter 601, manufactured by EI was used, Digital TDS meter -651 manufactured by EI was used to determine the TDS of the waste water sample, The BOD tests were carried out using standard procedure using a five-day BOD test whileChemical Oxygen Demand (COD) was determined by the Dichromate Reflux Method.

\section{Experimental Result Analysis}

The analyzed data revealed the variation between the test samples, the result of analysis of various parameters of effluent are summarized in table -1 and 2 and comparison showed from figure 1-5. 
Table 1.1 Physiochemical parameters of Sanganer printing cluster

\begin{tabular}{|c|c|c|c|c|c|}
\hline Sample & BOD(mg/l) & COD(mg/l) & TDS(mg/l) & pH & EC(ms) \\
\hline $\mathbf{S N}_{\mathbf{1}}$ & 400 & 1900 & 5200 & 8.6 & 3.5 \\
\hline $\mathbf{S N}_{\mathbf{2}}$ & 425 & 2500 & 4500 & 8.7 & 3.35 \\
\hline $\mathbf{S N}_{\mathbf{3}}$ & 410 & 2200 & 4650 & 9.6 & 3.38 \\
\hline
\end{tabular}

Here: $\mathbf{E C}=$ Electrical conductivity; $\mathbf{T D S}=$ Total Dissolved Solids; $\mathbf{B O D}=$ biological oxygen demand. COD=Chemical Oxygen Demand.

Table 1.2 Physiochemical parameters of Bagru printing cluster

\begin{tabular}{|c|c|c|c|c|c|}
\hline Sample & $\mathbf{B O D}(\mathbf{m g} / \mathbf{l})$ & $\mathbf{C O D}(\mathbf{m g} / \mathbf{l})$ & $\mathbf{T D S}(\mathbf{m g} / \mathbf{l})$ & $\mathbf{p H}$ & $\mathbf{E C}(\mathbf{m s})$ \\
\hline $\mathbf{B G}_{\mathbf{1}}$ & 390 & 1600 & 2245 & 6.54 & 2.19 \\
\hline $\mathbf{B G}_{\mathbf{2}}$ & 405 & 1650 & 2658 & 6.97 & 2.42 \\
\hline $\mathbf{B G}_{\mathbf{3}}$ & 435 & 1345 & 3463 & 7.23 & 2.23 \\
\hline
\end{tabular}

Here: $\mathbf{E C}=$ Electrical conductivity; $\mathbf{T D S}=$ Total Dissolved Solids; $\mathbf{B O D}=$ biological oxygen demand COD=Chemical Oxygen Demand.

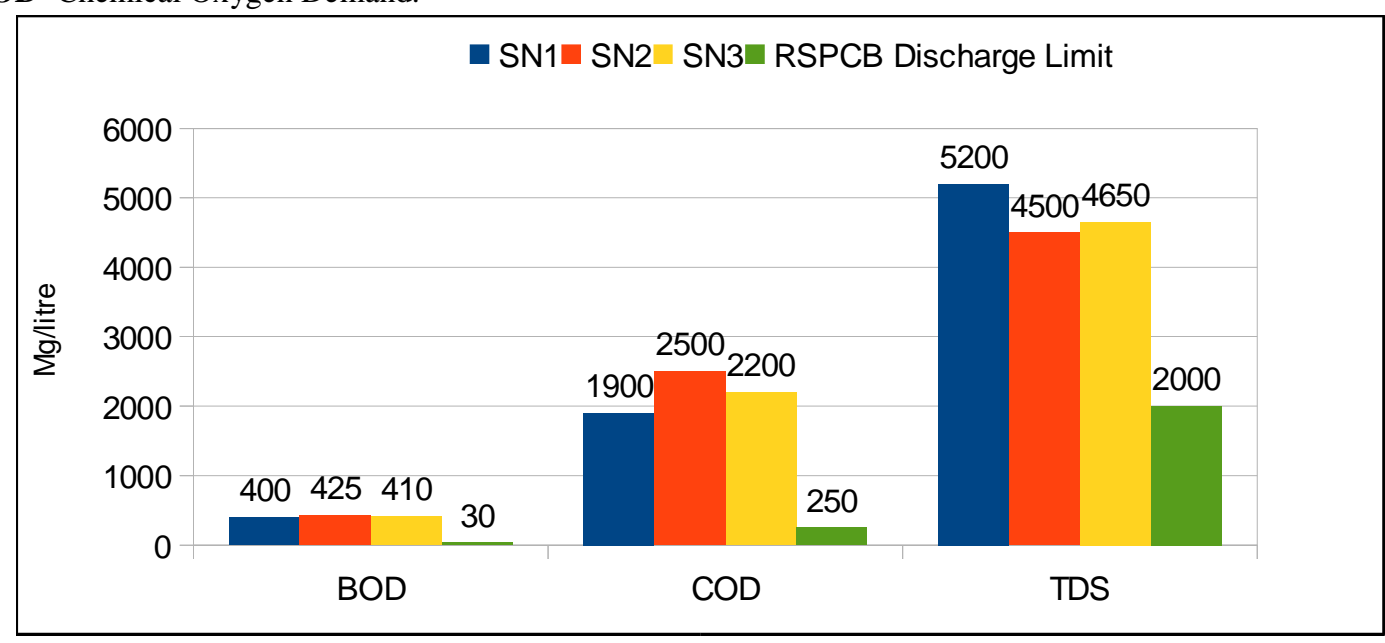

Figure -1 Comparative analysis of BOD, COD, and TDS of Sanganer Samples with Discharge Limit prescribed by RPCB.

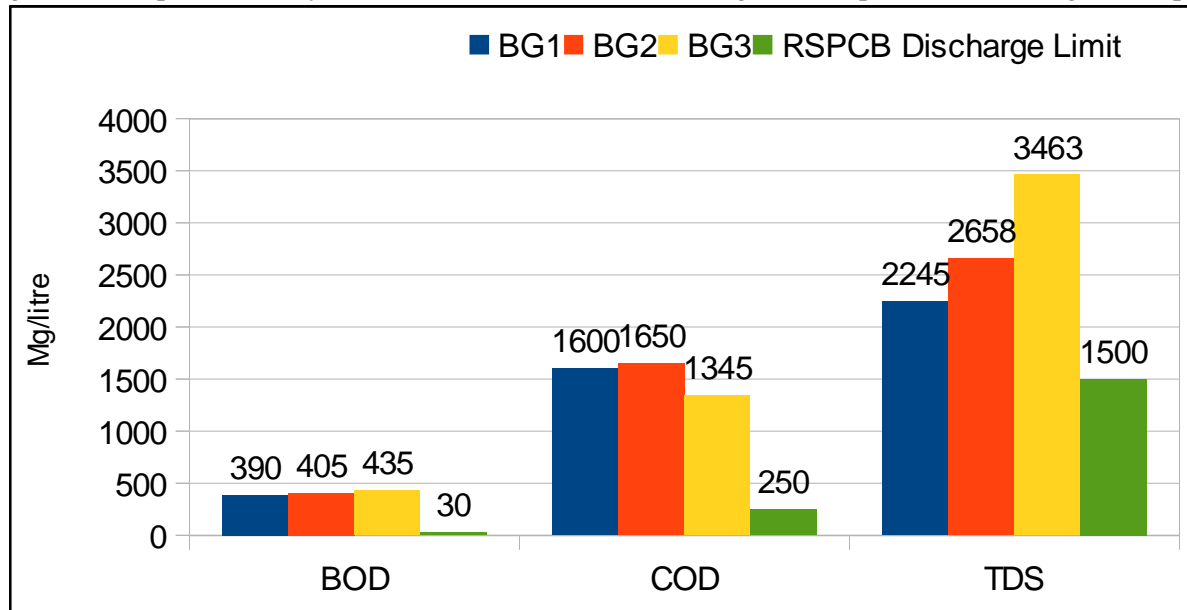

Figure -2 Comparative analysis of BOD, COD, and TDS of Bagru Samples with Discharge Limit prescribed by RPCB. 


\subsection{Biological oxygen demand, Chemical oxygen demand and Total Dissolved Solids}

Figure -1 and 2 Showed that in Sanganer sample BOD range is 400-425 mg/l and in Bagru 390-435 $\mathrm{mg} / \mathrm{l}$, which is higher then prescribed limit (30mg/l) by RPCB and COD ranged for Sanganer and Bagru Cluster are $250-2500 \mathrm{mg} / \mathrm{l}$ and $250-1650 \mathrm{mg} / \mathrm{l}$ respectively, which is also higher from discharge limit $250 \mathrm{mg} / \mathrm{l}$. TDS ranged for both cluster also higher then prescribed limit $(2000 \mathrm{mg} / \mathrm{l})$.

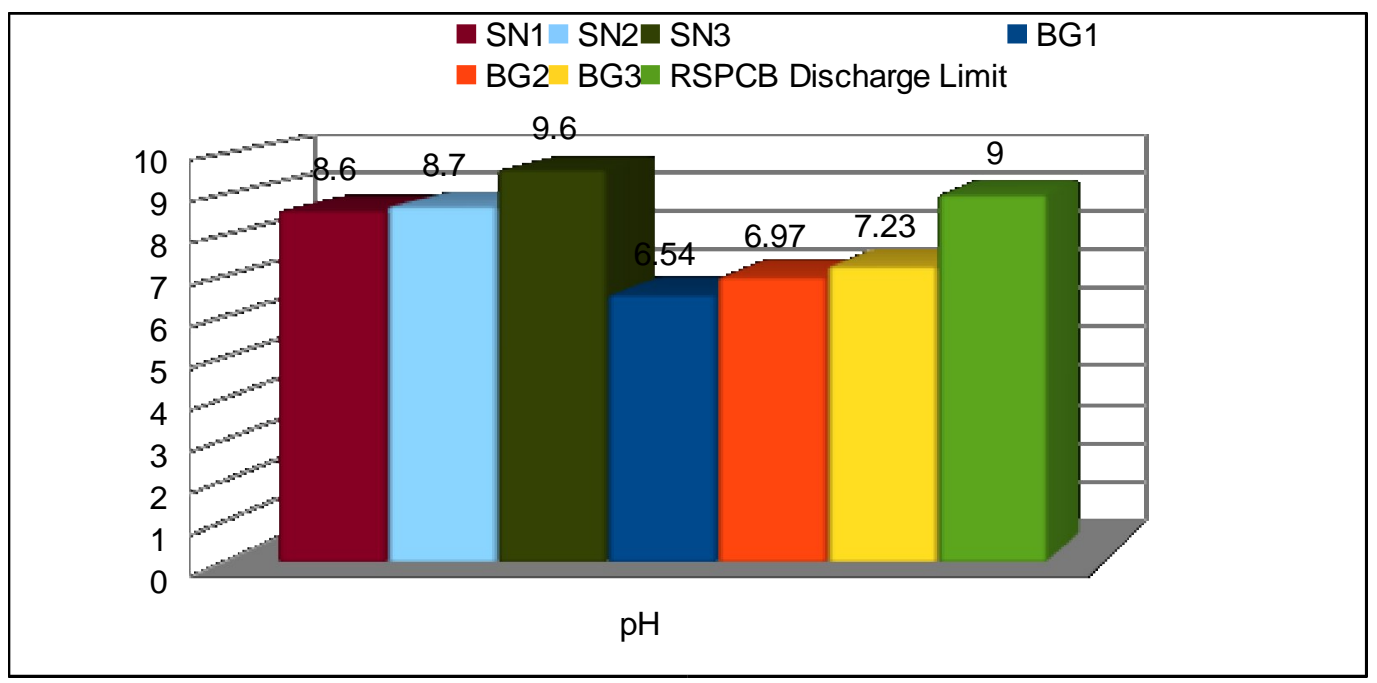

Figure -3 Comparative analysis of pH of Snaganer and Bagru Samples with Discharge Limit prescribed by RPCB.

\subsection{Hydrogen ion concentration (pH)}

$\mathrm{pH}$ is the negative logarithm of $\mathrm{H}+$ ion concentration. It indicates the intensity of acidic or basic characteristics of water. Measurement of $\mathrm{pH}$ is necessary at each step of water treatment or water supply like acid base neutralization. Water softening, coagulation, disinfection, corrosion control etc. The $\mathrm{pH}$ of the water sample were found in the range of 6.7 to 8.9 for Bagru and 6.9 to 9.5 for Sanganer which is close to alkaline region. The maximum $\mathrm{pH}$ value prescribed by $\mathrm{WHO}$ is 7.0 to 8.50 . Both the printing clusters have $\mathrm{pH}$ values with in the desirable and suitable range.

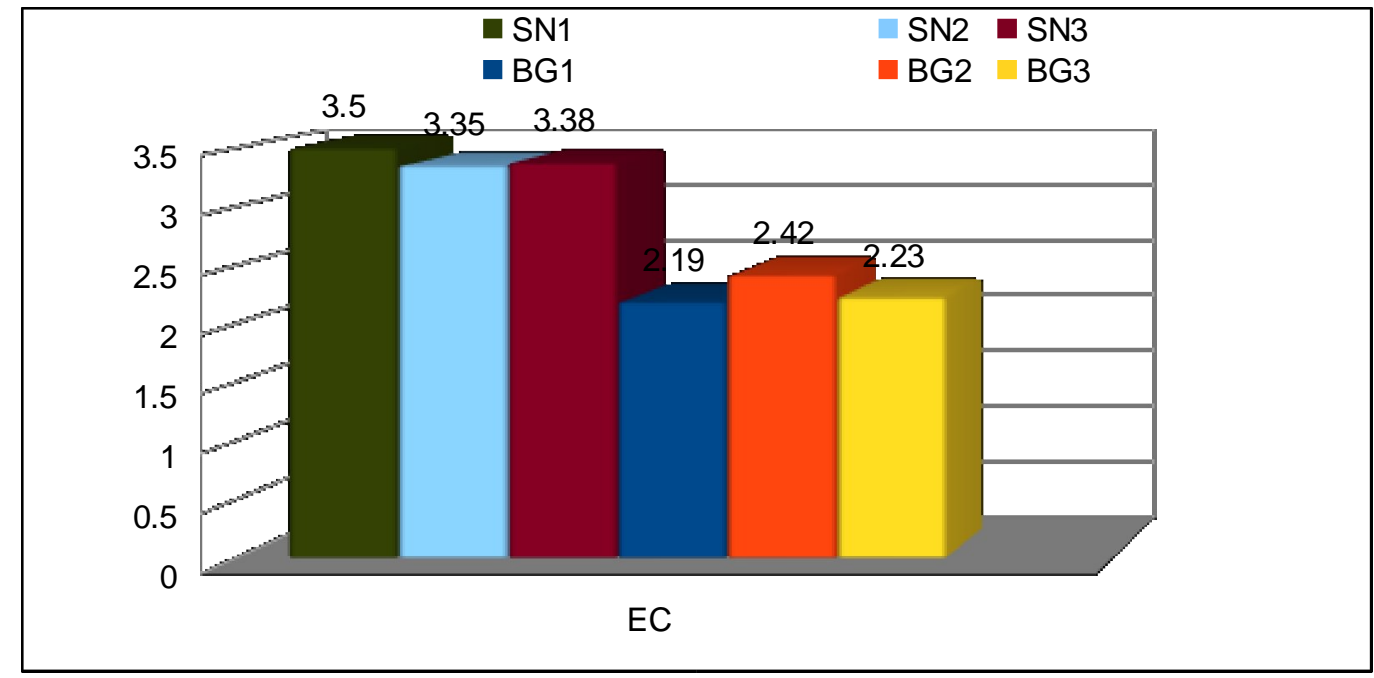

Figure -3 Comparative analysis of EC of Snaganer and Bagru Samples with Discharge Limit prescribed by RPCB.

\subsection{Electrical Conductivity}

Electrical conductivity refers to the number of ions in any solution. These ions carry an electric current. Higher value of electrical conductivity shows higher concentrations of dissolved ions. Conductivity is an important criterion to determine the suitability of water for irrigation. The conductivity of the water samples was $1.42-4.16 \mathrm{~ms} \& 3.5-4.5 \mathrm{~ms}$ for Bagru \& Sanganer area, respectively, which is much below the WHO standards. 


\section{Conclusion}

The above results leads the following conclusions which indicates towards the necessity of textile waste water treatment at the source because it is not done these dye impurities enters into the cycle and cause various problems to consumer, the results indicate that the textile waste effluents in both the printing clusters is highly loaded with dye impurities, which directly affects the chemical oxygen demand of the water. Such type of water can't be used for irrigation purpose without treatment because these dye impurities like modarnts are carcinogenic in nature. These impurities deposit in the vegetables and other crops which are cultivated in this water. Data also indicates that the values of parameter $\mathrm{pH}$ is with in the WHO permissible limits for drinking water whereas electrical conductivity is much higher than permissible limits for Sanganer region than Bagru. The present study also indicates the lower ratio of COD/BOD. As we know that BOD is a measure of the quantity of dissolved oxygen in milligrams per litre necessary for the decomposition of organic matter by microorganisms such as bacteria and COD is a water quality measure used not only to measure the amount of biologically active substances such as bacteria but also biologically inactive organic matter in water. The permissible limit of BOD is $30 \mathrm{mg} / \mathrm{l}$ Whereas it is $250 \mathrm{mg} / \mathrm{l}$ for COD. Hence, the ratio between two must be 8.33 while it lies between 3 to 6 for various textile effluents which quite low from the prescribed limitless optimize the impurities from water resources it is necessary to treat the polluted effluent at the source \& only treated water should be dumped into water reservoir. Natural dyes should be preferred over synthetic dyes because the present study reveals that the water samples taken from Bagru printing area is less polluted compare to Sanganer printing area where synthetic dyes are used majorly.

\section{Acknowledgment}

Special thanks to the Honorable Chancellor Mr. Sandeep Bakshi, Jaipur National University as well as the for their motivation and financial support and Ms. Akanksha Gaur, Assistant Professor in Computer Engineering, Jaipur National University for her assistance.

\section{References}

[1] APHA (1992) Standard methods for the examination of water and waste water, American Public Health Association (18 ${ }^{\text {th }}$ Ed) Academic Press, Washington DC, 214- 218.

[2] Agarwal R, Agarwal SK (1990) Physico-chemical characteristics of saree printing effluent, its effect on seed germination and seedling growth of Cymopsis tetragonoloba. Acta Ecol Sin, 12:112-118.

[3] B.I.S. Bureau of Indian Standards Drinkingwater specification, Ist revision, ISS 10500(1991).

[4] Gebeyaw Damte "Implementing TQM in the technical service of Ethiopian airlines", AAU, Technology faculty, 2001

[5] Gupta, S. C. and Kapoor, V. K., Fundamentals of Applied Statistics, Sultan Chand \& Sons, New Delhi, 2007

[6] Indian Standards Institute (ISI), Tolerance Limit for Industrial Effluents Discharged on Land for Irrigation Purposes, IS: 3307 (1977).

[7] Joshi, P.C and Singh, Analysis of certainphysico-chemical parameters and planktonsof fresh water hill stream at Nanda Devibiosphere reserve. Uttar Pradesh J. Zoo., 21:177-179 (2001).

[8] John Oakland, "Total Quality Management Text with Cases “, Butterworth-Heine, 2000.

[9] Juran, Joseph M. Quality Control Handbook. 4th ed. New York: McGraw-Hill, 1988.

[10] Leaf, G. A. V., Practical Statistics for the Textile Industry: Part II, The Textile Institute, UK, 1984.

[11] Moyle, J., Relationship between thechemistry and Minnesota surface waters andwild life management.J. Wild L. Marg,20:149CHOUDHARY et al., Curr. World Environ., Vol. 6(1), 145-149 (2011)303-320 (1956).

[12] Narwal R.P., A.P. Gupta, A. Singh and S.P.S. Karwasra, Composition of Some City Waste Waters and Their Effect on Soil Characteristics, Ann. Biol., 9, 239 . 245 (1993).

[13] NEERI (1991). Manual on water and wastewater analysis. National EnvironmentalEngineering Research Institute, Nagpur.

[14] Patel H. and Pandey S., Physico-chemical characterization of textile chemical sludge generated from various CETPS in India, $J$. Environ. Res. Develop., 2(3), 329-339, (2008).

[15] Prasad D.Y. \& Qayyum, M.A., Pollutionaspects of Upper Lake Bhopal. Indian Journalof Zoology 4(1): 35-46 (1976).

[16] Rai H, Bhattacharya M, Singh J, Bansal TK, Vats P, Banerjee UC (2005) Removal of dyes from the effluent of textile and dyestuff manufacturing industry; Emerging techniques with reference to biological treatment: a review. Environ Sci Technol, 35: 219-238.

[17] Sastry, K. V. and Prathima Rathee, Physico-chemical and microbiological characteristics of water of village Kanneli (distt. Rohtak),Haryana. Proc. Acad. Biol., 7(1): 103-108(1998).

[18] Sharma, D.K., J.P. Jangir, C.P.S. Chandel and C.M. Gupta, Studies in Quality of Water in and around Jaipur. Part I, J. Indian Water Works Association, 257.260 (1988).

[19] Sharma Alka, Sharma D.K., J.P. Jangir and C.M. Gupta, Studies of Trace Elements in Water in and Around Jaipur, Indian Journal of Environ. Prot., 9(4), 294.296 (1989).

[20] Singh, A, Environmental chemistry(Istedn.).Campus books international, Delhi(2006).

[21] Singh, R.P.and Mathur, P., investigation ofvariations in physico chemical characteristicsof fresh water reservoir of Ajmer city, Rajasthan, Ind. J. Env., 9: 57-61 (2005).

[22] WHO. Guidelines for technologies for water supply systems in small communities (World Health Organization, CEHA) (2006).

[23] Yusuf, R.O. and Sonibare, J.A. (2004) Characterisation of textile industries effluents in Kaduna, Nigeria and Olayinka, Studies on industrial pollution in Nigeria. The effects of textile effluents on the quality of ground water in some parts of Lagos, Nigerian Journal of Health and Biomedical Sciences vol.3 pp 44-50. 